\title{
Doses of Algae Extract and Bacillus subtilis in Sorghum Crop
}

\author{
Vanessa Dias Rezende Trindade ${ }^{1}$, Ronaldo da Silva Viana ${ }^{2}$, Marco Eustáquio de Sá $^{3}$, Fernando Buzo ${ }^{4}$, \\ Gláucia Amorim Faria ${ }^{5}$, André Luís Silva Máximo ${ }^{6}$ \\ ${ }^{1,4}$ Graduate Student Master, Production Systems, Sao Paulo State University, Ilha Solteira, Brazil \\ ${ }^{2,3,5}$ Professor, Sao Paulo State University, Ilha Solteira, Brazil
}

${ }^{6}$ Agronomic Engineering, Sao Paulo State University, Ilha Solteira, Brazil

\begin{abstract}
Sorghum is grass with high production potential in periods with water deficit due to its tolerance metabolism to certain adverse conditions. Thus, this crop has become the primary alternative for replacing corn in rations in the meat production sector. Thus, the objective was to evaluate agronomic characteristics of sorghum submitted to different doses of algae extract in the presence or absence of Bacillus subtilis. A randomized complete block design was used in a $5 \times 2$ factorial scheme, with five doses $(0.0,0.5,1.0,1.5$ and 2.0 L.ha $\mathrm{L}^{-1}$ ) of seaweed extract and two situations (absence and presence of B. subtilis at a dose of 1.0 L.ha $^{-1}$ ), with four repetitions each treatment. The analyzed variables plant height and stem diameter were evaluated at 14, 21, 28, 35 and 42 DAS. Root volume, root dry matter, shoot dry matter and root dry matter/root volume ratio were evaluated at $42 \mathrm{DAS}$ at the time of the experiment harvest. The stem diameter was higher at zero doses of algae extract and for Bacillus subtilis application, but the absence of the bacteria promoted higher root volume. Thus, with the increase of the stem diameter, it is possible to accumulate photoassimilates, increasing the dry mass content produced.
\end{abstract}

Keywords: diazotrophic bacteria, productivity, biomass

\section{Introduction}

Sorghum (Sorghum bicolor (L.) Moench) belongs to the Poaceae family, being the fifth most cultivated cereal in the world. Of African origin, this species is widespread in Asia and Africa, as well as semi-arid regions, being part of human food. In the West, its use is directed to animal feed, both in the form of grain and whole plant silage. Sorghum is a crucial alternative for regions with low rainfall due to its ability to tolerate water stress, making it a cost-effective crop for low production costs. Also, it is versatile in terms of use (silage, hay, or direct grazing), has high production potential, and is an essential source of energy for animals [9].

During the development of the crop, fertilization is fundamental for the correct functioning of metabolic processes. However, the use of improper chemical fertilizers in the long term can generate high production costs, besides contaminating groundwater with nutrient leaching, causing an imbalance in the soil microorganism population [7]. In this scenario, it was seen the need to study sustainable fertilization alternatives, using other types of products, such as biostimulants, which have shown to influence root growth and nutrient absorption. Biostimulant substances can be classified into four groups, namely humic substances, protein hydrolyzate, and amino acid formulations, seaweed extract, and growth-promoting microorganisms [13].

Among the plant growth-promoting bacteria, there is the genus Bacillus, which, like Azospirillum, can play a fundamental role in crop development. Bacteria of this genus may contribute to drought tolerance, as found in studies that show strains that are capable of developing in water stress from protective mechanisms that induce exopolysaccharide and biofilm production. They can also contribute to plant growth through phosphorus availability, nitrogen fixation, and phytohormone production [17].

Another alternative to the context studied is the use of mixed mineral fertilizers with algae extract applied via leaf. Algae extract is a biostimulant compound and has been added to mineral fertilizers due to its physioactivating effect. It is responsible for inducing vegetative growth, favoring root development, and contributing to the defense of pathogens. Besides, it can improve the efficiency of nutrients contained in fertilizers by increasing their absorption, thereby increasing their utilization [2].

Leaf fertilization can be used to correct any deficiencies during other operations such as insecticide and fungicide application. Due to the small amounts required of micronutrients by plants, the application cost becomes relatively low. Also, foliar fertilization reduces the amount of fertilizer needed when compared to soil, can achieve more excellent distribution uniformity and rapid response to growth deficiencies, reducing effects on yield [5]. However, even though it is more efficient in the immediate availability of nutrients, foliar fertilization does not replace conventional fertilization [4].

In this scenario, reducing production costs for sorghum cultivation may provide higher profitability, especially for resource-poor regions, as this grass is fundamental to food security in many countries. Thus, this work aimed to evaluate agronomic characteristics of double sorghum submitted to different doses of algal extract mixed leaf fertilizer in the presence or absence of Bacillus subtilis.

\section{Volume 9 Issue 2, February 2020




\section{International Journal of Science and Research (IJSR) \\ ISSN: 2319-7064}

ResearchGate Impact Factor (2018): 0.28 | SJIF (2018): 7.426

\section{Research Methods}

The experiment was conducted at the Teaching, Research and Extension Farmof Sao Paulo State University, Campus of Ilha Solteira, located in Selvíria-MS, with geographic coordinates latitude $20^{\circ} 20^{\prime} 48,10^{\prime \prime} \mathrm{S}$ and longitude $51^{\circ}$ $24 ' 35,85^{\prime \prime} \mathrm{W}$, from March to May of 2019. Installed in the seedling nursery with $50 \%$ shading screen in eight-liter pots with supplementary sprinkler irrigation. The soil was collected on the farm itself and classified as a typical clayey dystrophic Red Latosol [8]. The material was collected and sent to the soil analysis laboratory, as shown in Table 1.

Fertilization was performed at sowing with fertilizer NPK 04-14-08 at a dose of $300 \mathrm{~kg} \mathrm{ha}^{-1}$, and, at 14 days after sowing (DAS), fertilization with urea was performed at recommendation $100 \mathrm{~kg} \mathrm{ha}^{-1}$. Sowing was performed in April 2019, with three seeds distributed per pot in uniform spacing. The cultivar used was double-capacity sorghum Silotec-20, with a purity of $98 \%$ and germination of $80 \%$. The seeds were treated with a fungicide dicarboximide group.

Table 1: Characterization of macronutrients and micronutrients in the 0.00 to $0.20 \mathrm{~m}$ layer

\begin{tabular}{|c|c|c|c|c|c|c|c|c|c|}
\hline \multicolumn{10}{|c|}{ Macronutrientes } \\
\hline \multirow{2}{*}{ Layer } & \multirow{2}{*}{$\begin{array}{c}\mathrm{P} \\
\left(\mathrm{mg} \mathrm{dm}^{-3}\right)\end{array}$} & \multirow{2}{*}{$\begin{array}{c}\mathrm{OM} \\
\left(\mathrm{g} \mathrm{dm}^{-3}\right)\end{array}$} & $\mathrm{pH}$ & $\mathrm{K}$ & $\mathrm{Ca}^{2+}$ & $\mathrm{Mg}^{2}$ & $\mathrm{Al}^{3+}$ & CEC & \multirow{2}{*}{$\begin{array}{c}\mathrm{S} \\
(\%)\end{array}$} \\
\hline & & & \multicolumn{6}{|c|}{ mmolc dm ${ }^{-3}$} & \\
\hline $0,00-0,20 \mathrm{~m}$ & 4 & 17 & 4,4 & 0,6 & 7 & 7 & 4 & 52,6 & 28 \\
\hline \multicolumn{10}{|c|}{ Micronutrientes } \\
\hline \multirow{2}{*}{ Layer } & $\mathrm{B}^{-}$ & $\mathrm{C}$ & & & $\mathrm{Ir}^{2+}$ & & $\mathrm{Mn}^{2+}$ & & $\mathrm{Zn}^{2+}$ \\
\hline & \multicolumn{9}{|c|}{ mmolc $\mathrm{dm}^{-3}$} \\
\hline $0,00-0,20 \mathrm{~m}$ & 0,09 & 1 , & & & 16 & & 8,5 & & 0,1 \\
\hline
\end{tabular}

Phosphorus (P); Organic Matter (OM); pH (Hydrogen potential), Potassium (K), Calcium (Ca), Magnesium $(\mathrm{Mg})$, Aluminum (Al), Cation Exchange Capacity (CEC); Base Saturation (\%), Boron (B), Cuper (Cu), Iron (Fe), Manganese (Mn), Zinc (Zn).Source: Soil Fertility Laboratory of the Department of Plant Health, Rural Engineering and Soils of Sao Paulo State University, Ilha Solteira, 2019.

A randomized complete block design was used in a $5 \times 2$ factorial scheme, with five doses $(0.0,0.5,1.0,1.5$ and 2.0 $\mathrm{Lha}^{-1}$ ) of mineral fertilizer containing algae extract and $10 \%$ zincand two situations (absence and presence of B. subtilis at a dose of $1.0 \mathrm{~L}$. ha ${ }^{-1}$ ), with four repetitions, totaling 40 pots. The treatments were applied at five days after sowing (DAS) via leaf spraying on seedlings. The spraying was performed in the morning at $9 \mathrm{am}$, using as reference the volume of syrup 150 liters. From this volume, proportional dilution to one liter was performed, and each dose applied separately. Immediately afterward, Bacillussubtilis was applied at a dose of $1.0 \mathrm{~L} \mathrm{ha}^{-1}$, using the same volume of syrup as a reference, and proportional dilution to one liter of syrup.

The analyzed variables plant height and stem diameter were evaluated at 14, 21, 28, 35 and 42 DAS. Root volume, root dry matter, shoot dry matter and root dry matter/root volume ratio were evaluated at $42 \mathrm{DAS}$ at the time of the experiment harvest.

Statistical analysis was performed by the Agroestat program through an analysis of variance by the F Test and linear regression to find an adjusted model [3].

\section{Results and Discussion}

Regarding plant height, according to Table 2, there was no statistical difference between the doses of mixed mineral fertilizer with algae extract in any of the evaluation periods, and no regression model adjusted to the data was found, in disagreement. Studies that evaluated mineral fertilizer composed of zinc and molybdenum and found that the $0.3 \mathrm{~L}$ $\mathrm{ha}^{-1}$ dose promoted longer plant length [6]. When evaluating zinc and boron doses via soybean leaf, no significant difference was found between treatments for plant height [15]. In a study evaluating biostimulants in maize, culture found that plant height was not influenced [10]. n a study evaluating algal extract in wheat plants found that this biostimulant did not interfere with plant length, in agreement with the present study [11].

As for the bacterium Bacillussubtilis there was no statistical difference for the presence and absence of the bacterium, which may indicate that its application does not influence plant height at an early stage of development. Evaluating different isolates of growth-promoting bacteria and their effects on corn and sorghum growth, Bacillussubtilis isolates promoted intermediate heights, providing higher nitrogen levels compared to treatment without nitrogen fertilization [1].

When the stem diameter of the plants was analyzed (Table 3 ), a statistical difference was found between fertilizer doses at 14DAS, and the data fit the linear regression model. For the other evaluation times, no statistical differences were found for doses. Accordingly, no statistical difference was found for corn stalk diameter when evaluating different doses of humic substances and amino acids-based biostimulant [10]. In contrast, when evaluating the foliar application of manganese and silicon to maize plants, it found a larger stem diameter by applying $0.58 \mathrm{~g} \mathrm{~L}^{-1}$ manganese in the presence of silicon [16]. According to this work, this behavior in maize plants can be extrapolated to sorghum ones, because they have similar physiological systems.

Volume 9 Issue 2, February 2020

www.ijsr.net

Licensed Under Creative Commons Attribution CC BY 


\section{International Journal of Science and Research (IJSR) \\ ISSN: 2319-7064}

ResearchGate Impact Factor (2018): 0.28 | SJIF (2018): 7.426

Table 2: Test $F$ values of plant height $(\mathrm{cm})$ when applied doses of algal extract $\left(\mathrm{L} \mathrm{ha}^{-1}\right)$ with or without Bacillus subtilis. Selvíria, 2019

\begin{tabular}{|c|c|c|c|c|c|c|}
\hline \multirow{2}{*}{\multicolumn{2}{|c|}{ Sources of Variation }} & \multicolumn{5}{|c|}{ Plant Height $(\mathrm{cm})$} \\
\hline & & \multicolumn{5}{|c|}{ 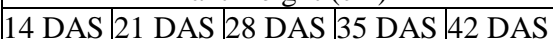 } \\
\hline \multicolumn{2}{|c|}{ Doses } & \multicolumn{5}{|c|}{ Means } \\
\hline \multicolumn{2}{|c|}{0} & 5,30 & 8,86 & 11,68 & 19,39 & 25,65 \\
\hline \multicolumn{2}{|c|}{0,5} & 4,98 & 9,09 & 12,77 & 18,79 & 25,85 \\
\hline \multicolumn{2}{|c|}{1,0} & 5,35 & 9,45 & 12,57 & 17,99 & 27,18 \\
\hline \multicolumn{2}{|c|}{1,5} & 5,59 & 9,64 & 12,15 & 18,89 & 26,58 \\
\hline \multicolumn{2}{|c|}{2,0} & 4,99 & 8,13 & 11,45 & 16,91 & 24,16 \\
\hline \multicolumn{2}{|c|}{ Bacillus subtilis } & \multicolumn{5}{|c|}{ Means } \\
\hline \multicolumn{2}{|c|}{ With } & 5,25 & 8,76 & 12,06 & 18,14 & 25,55 \\
\hline \multicolumn{2}{|c|}{ Without } & 5,23 & 9,30 & 12,19 & 18,61 & 26,22 \\
\hline \multicolumn{2}{|c|}{ Doses } & $0,77^{\mathrm{ns}}$ & $2,37^{\mathrm{ns}}$ & $0,72^{\mathrm{ns}}$ & $1,94^{\mathrm{ns}}$ & $0,63^{\mathrm{ns}}$ \\
\hline \multicolumn{2}{|c|}{ Bacillus subtilis } & $0,00^{\mathrm{ns}}$ & $2,43^{\mathrm{ns}}$ & $0,05^{\mathrm{ns}}$ & $0,47^{\mathrm{ns}}$ & $0,27^{\mathrm{n}}$ \\
\hline \multicolumn{2}{|c|}{$\mathrm{D} \times \mathrm{B}$} & $1,73^{\mathrm{ns}}$ & $2,01^{\mathrm{ns}}$ & $1,35^{\mathrm{ns}}$ & $1,44^{\mathrm{ns}}$ & $2,39^{\mathrm{ns}}$ \\
\hline \multicolumn{2}{|c|}{$\mathrm{VC}(\%)$} & 15,96 & 11,99 & 15,47 & 10,70 & 15,67 \\
\hline \multirow{3}{*}{ Regression } & Linear & $0,00^{\mathrm{ns}}$ & $0,58^{\mathrm{ns}}$ & $0,26^{\mathrm{ns}}$ & $4,87^{*}$ & $0,24^{\mathrm{ns}}$ \\
\hline & Quadı & $0,40^{\mathrm{ns}}$ & $6,47^{*}$ & $2,33^{\mathrm{ns}}$ & $0,17^{\mathrm{ns}}$ & $1,78^{\mathrm{n}}$ \\
\hline & Detour & $0,00^{\mathrm{ns}}$ & $0,14^{\mathrm{ns}}$ & $0,04^{\mathrm{ns}}$ & $1,24^{\mathrm{ns}}$ & $0,07^{\mathrm{n}}$ \\
\hline
\end{tabular}

Averages followed by the same letter do not differ from each other in the columns by the $5 \% \mathrm{~F}_{\text {test. }}{ }^{\mathrm{ns}}=$ not significant.

Regarding the bacteria, at 21DAS, a significant difference was found, and the absence of the bacteria provided a larger stem diameter when compared to the presence of Bacillus subtilis. Accordingly, studies have found that among the growth-promoting bacteria groups, the Bacillussubtilis species promoted a smaller sorghum diameter than the other bacteria studied [1]. Regarding the diameter at 28DAS (Table 4), it is verified that the absence of Bacillus subtilis promoted a larger diameter about the bacteria application. In a study with genus Bacillus, when compared to Azospirillum and Pseudomonas, it promotes smaller diameter of corn and sorghum plants [1].

Table 3: Test $F$ values of stem diameter $(\mathrm{mm})$ when applied doses of algal extract $\left(\mathrm{L} \mathrm{ha}^{-1}\right)$ with or without Bacillus subtilis. Selvíria, 2019

\begin{tabular}{|c|c|c|c|c|c|c|}
\hline \multirow{2}{*}{\multicolumn{2}{|c|}{ Sources of Variation }} & \multicolumn{5}{|c|}{ Stem Diameter (mm) } \\
\hline & & $14 \mathrm{DAS}$ & $21 \mathrm{DAS}$ & $28 \mathrm{DAS}$ & $35 \mathrm{DAS}$ & $42 \mathrm{DAS}$ \\
\hline \multicolumn{2}{|c|}{ Doses } & \multicolumn{5}{|c|}{ Means } \\
\hline \multicolumn{2}{|c|}{0} & 1,83 & 3,07 & 4,15 & 5,98 & 7,23 \\
\hline \multicolumn{2}{|c|}{0,5} & 1,71 & 3,45 & 4,41 & 5,63 & 7,08 \\
\hline \multicolumn{2}{|c|}{1,0} & 1,74 & 3,05 & 4,57 & 6,03 & 7,38 \\
\hline \multicolumn{2}{|c|}{1,5} & 1,58 & 3,38 & 4,53 & 6,22 & 7,78 \\
\hline \multicolumn{2}{|c|}{2,0} & 1,63 & 3,00 & 3,60 & 5,63 & 7,11 \\
\hline \multicolumn{2}{|c|}{ Bacillus subtilis } & \multicolumn{5}{|c|}{ Means } \\
\hline \multicolumn{2}{|c|}{ With } & 1,70 & $2,91 \mathrm{~b}$ & 4,22 & 6,09 & 7,40 \\
\hline \multicolumn{2}{|c|}{ Without } & 1,69 & $3,48 \mathrm{a}$ & 4,28 & 5,70 & 7,24 \\
\hline \multicolumn{2}{|c|}{ Doses } & $3,58^{*}$ & $1,50^{\mathrm{ns}}$ & $2,14^{\mathrm{ns}}$ & $1,25^{\mathrm{ns}}$ & $0,41^{\mathrm{ns}}$ \\
\hline \multicolumn{2}{|c|}{ Bacillus subtilis } & $0,04^{\mathrm{ns}}$ & $14,08^{*}$ & $0,06^{\mathrm{ns}}$ & $3,88^{\mathrm{ns}}$ & $0,17^{\mathrm{ns}}$ \\
\hline \multicolumn{2}{|c|}{$\mathrm{D} \times \mathrm{B}$} & $1,32^{\mathrm{ns}}$ & $2,18^{\mathrm{ns}}$ & $0,30^{\mathrm{ns}}$ & $1,46^{\mathrm{ns}}$ & $0,82^{\mathrm{ns}}$ \\
\hline \multicolumn{2}{|c|}{$\mathrm{VC}(\%)$} & 8,37 & 15,04 & 18,07 & 11,14 & 17,24 \\
\hline \multirow{3}{*}{ Regression } & Linear & $10,58^{*}$ & $0,15^{\mathrm{ns}}$ & $1,32^{\mathrm{ns}}$ & $0,02^{\mathrm{ns}}$ & $0,11^{\mathrm{ns}}$ \\
\hline & Quadratic & $0,60^{\mathrm{ns}}$ & $1,58^{\mathrm{ns}}$ & $6,33^{*}$ & $0,61^{\mathrm{ns}}$ & $0,32^{\mathrm{ns}}$ \\
\hline & Detour & $3,02^{\mathrm{ns}}$ & $4,26^{*}$ & $0,07^{\mathrm{ns}}$ & $0,05^{\mathrm{ns}}$ & $0,05^{\mathrm{ns}}$ \\
\hline
\end{tabular}

Averages followed by the same letter do not differ from each other in the columns by the $5 \% \mathrm{~F}_{\text {test. }}{ }^{\mathrm{ns}}=$ not significant.
Table 4: Splitting Test F values for stem diameter ( $\mathrm{mm}$ ) when applying doses of algal extract $\left(\mathrm{L} \mathrm{ha}^{-1}\right)$ with or without Bacillus subtilis. Selvíria, 2019

\begin{tabular}{|c|c|}
\hline \multicolumn{2}{|c|}{ Stem Diameter (mm) } \\
\hline Bacillus subtilis & 28 DAS \\
\hline Without & $3,48 \mathrm{a}$ \\
\hline With & $2,91 \mathrm{~b}$ \\
\hline SMD (5\%) & 0,3120 \\
\hline
\end{tabular}

Averages followed by the same letter do not differ from each other in the columns by the $5 \% \mathrm{~F}$ test. ${ }^{\mathrm{ns}}=$ not significant. $\mathrm{SMD}=$ Significant minimum difference.

Figure 1 shows the regression model adjusted for stem diameter at 14DAS, with a decreasing linear model with the significant correlation coefficient. It is verified that the control (zero doses) of mineral fertilizer with algae extract provided a larger stem diameter about the other doses.

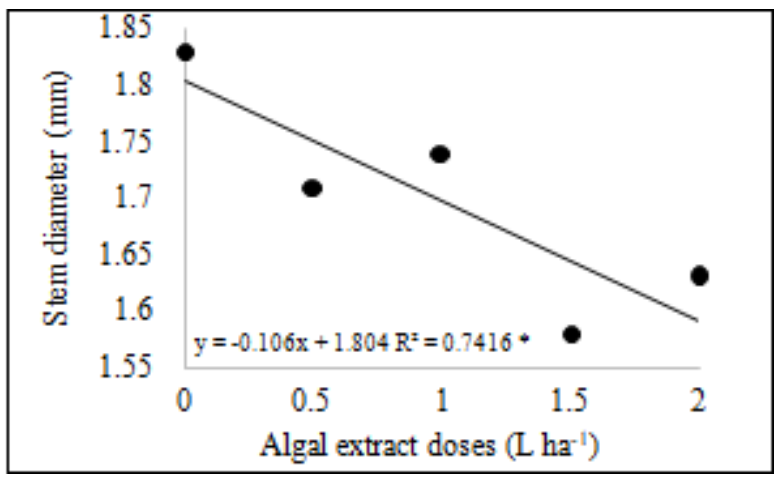

Figure 1: Regression model for stem diameter (mm) at 14 DAS for doses of algal extract $\left(\mathrm{L} \mathrm{ha}^{-1}\right)$. Selvíria, 2019

Regarding the evaluations at the end of the experiment (Table 5), the volume of sorghum roots at 42DAS showed no significant difference between fertilizer doses, in agreement with a study that evaluated the use of biostimulant in the initial development of corn and found no difference. statistics for root volume [14].

Shoot dry matter showed no statistical difference for the use of biostimulant leaf fertilizer, in agreement with a study that evaluated zinc and silicon foliar fertilization in maize and found no significant difference for shoot dry matter [12]. Like other studies also did not verify statistical differences between the presence or absence of biostimulant in corn plants [14].

As for root dry matter, the doses of leaf fertilizer were not different from each other, in disagreement with a study that obtained higher dry matter when applying $0.60 \mathrm{~g} \mathrm{~L}-1$ manganese in the presence of silicon [12]. No statistical difference was found between the presence or absence of biostimulant in the dry matter accumulation in the roots of maize plants [14].

Regarding Bacillus subtilis, a statistical difference was found, and the absence of the bacterium promoted higher root volume, representing an increase of $38.24 \%$ to the bacterium application. As for dry shoot matter, there was no statistical difference for the bacteria, in disagreement with studies that found that Bacillus subtilis promoted a high amount of shoot dry matter [1]. Similarly, dry root matter

\section{Volume 9 Issue 2, February 2020




\section{International Journal of Science and Research (IJSR) \\ ISSN: 2319-7064}

ResearchGate Impact Factor (2018): 0.28 | SJIF (2018): 7.426

did not distinguish between the presence or absence of bacteria. The isolates of the genus Bacillus promoted lower root dry mass of sorghum plants compared to other growthpromoting bacteria, although the growth provided by Bacillus subtilis was higher than the control without nitrogen fertilization [1]. Although no statistical differences were found, it is seen that there is a trend of $1.0 \mathrm{~L} \mathrm{ha}^{-1}$ dose along with the absence of bacteria favoring root-related variables, since it was presented high value for volume and root dry matter. In contrast, the presence of Bacillus subtilis may provide a higher value of dry shoot matter. Thus, the absence of the bacteria promoted higher root growth, since the necessary nutrients were not available at that initially explored volume, making growth fundamental in their search. These results contradict information from the literature, where there are studies that report the action of bacteria as a promoter of plant growth and root development.

Regarding root volume (Table 6), the absence of Bacillus subtilis promoted higher volume due to the more significant growth of the root system. This may have been due to the immediate nutrient availability offered by sowing fertilization, that is, even applying the bacterium at 5DAS, the time for the bacterium to establish its population among the microorganisms in the soil may have been longer than the experiment conduction period. , making it difficult to measure the benefits provided by the bacteria.

Table 5: Test $\mathrm{F}$ values for root volume $\left(\mathrm{dm}^{3}\right)$, shoot dry matter (DM) (g), root dry matter (g) and ratio between dry matterand root volume $\left(\mathrm{g} \mathrm{g} \mathrm{dm}^{-3}\right)$ at 42DAS when applied doses of algae extract $\left(\mathrm{L} \mathrm{ha}^{-1}\right)$ with or without Bacillus subtilis. Selvíria, 2019.

\begin{tabular}{|c|c|c|c|c|c|}
\hline \multicolumn{2}{|c|}{$\begin{array}{l}\text { Sources of } \\
\text { Variation }\end{array}$} & $\begin{array}{c}\text { Root } \\
\text { Volume } \\
\left(\mathrm{dm}^{3}\right)\end{array}$ & $\begin{array}{c}\text { Shoot Dry } \\
\text { Matter } \\
(\mathrm{g})\end{array}$ & \begin{tabular}{|c|} 
Root Dry \\
Matter \\
$(\mathrm{g})$
\end{tabular} & \begin{tabular}{|c}
$\begin{array}{c}\text { Shoot DM/ } \\
\text { Root Volume } \\
\left(\mathrm{g} \mathrm{dm}^{-3}\right)\end{array}$ \\
\end{tabular} \\
\hline \multicolumn{2}{|c|}{ Doses } & \multicolumn{4}{|c|}{ Means } \\
\hline \multicolumn{2}{|c|}{0} & 0,027 & 4,71 & 7,52 & 281,25 \\
\hline \multicolumn{2}{|c|}{0,5} & 0,026 & 6,15 & 6,32 & 158,37 \\
\hline \multicolumn{2}{|c|}{1,0} & 0,033 & 5,63 & 9,58 & 218,25 \\
\hline \multicolumn{2}{|c|}{1,5} & 0,027 & 5,91 & 9,06 & 219,75 \\
\hline \multicolumn{2}{|c|}{2,0} & 0,023 & 4,77 & 6,60 & 163,87 \\
\hline \multicolumn{2}{|c|}{ Bacillus subtilis } & \multicolumn{4}{|c|}{ Means } \\
\hline \multicolumn{2}{|c|}{ With } & $0,021 \mathrm{~b}$ & 5,58 & 7,60 & 225,20 \\
\hline \multicolumn{2}{|c|}{ Without } & $0,034 \mathrm{a}$ & 5,29 & 8,04 & 191,40 \\
\hline \multicolumn{2}{|c|}{ Doses } & $0,52^{\mathrm{ns}}$ & $1,93^{\mathrm{ns}}$ & $1,44^{\mathrm{ns}}$ & $2,33^{\mathrm{ns}}$ \\
\hline \multicolumn{2}{|c|}{ Bacillus subtilis } & $8,82^{*}$ & $0,45^{\mathrm{ns}}$ & $0,16^{\mathrm{ns}}$ & $1,33^{\mathrm{ns}}$ \\
\hline \multicolumn{2}{|c|}{$\mathrm{D} \times \mathrm{B}$} & $0,65^{\mathrm{ns}}$ & $1,06^{\mathrm{ns}}$ & $2,67^{\mathrm{ns}}$ & $0,49^{\mathrm{ns}}$ \\
\hline \multicolumn{2}{|c|}{$\mathrm{VC}(\%)$} & 52,08 & 24,69 & 43,89 & 44,51 \\
\hline \multirow{3}{*}{ Regression } & Linear & $0,14^{\mathrm{ns}}$ & $0,01^{\mathrm{ns}}$ & $0,05^{\mathrm{ns}}$ & $2,80^{\mathrm{ns}}$ \\
\hline & Quadratic & $0,98^{\mathrm{ns}}$ & $6,03^{*}$ & $1,93^{\mathrm{ns}}$ & $0,38^{\mathrm{ns}}$ \\
\hline & Detour & $0,78^{\mathrm{ns}}$ & $1,55^{\mathrm{ns}}$ & $0,99^{\mathrm{ns}}$ & $0,78^{\mathrm{ns}}$ \\
\hline
\end{tabular}

Averages followed by the same letter do not differ from each other in the columns by the $5 \% \mathrm{~F}$ test. ${ }^{\mathrm{ns}}=$ not significant.

Table 6: Splitting Test $F$ values for root volume $\left(\mathrm{dm}^{3}\right)$ when applied doses of algal extract $\left(\mathrm{L} \mathrm{ha}^{-1}\right)$ with or without Bacillus subtilis. Selvíria, 2019

\begin{tabular}{|c|c|}
\hline Bacillus subtilis & Root Volume $\left(\mathrm{dm}^{3}\right)$ \\
\hline Without & $0,034 \mathrm{a}$ \\
\hline With & $0,021 \mathrm{~b}$ \\
\hline SMD (5\%) & 0,0094 \\
\hline
\end{tabular}

Averages followed by the same letter do not differ from each other in the columns by the $5 \% \mathrm{~F}$ test. ${ }^{\text {ns }}=$ not significant. $\mathrm{SMD}=$ Significant minimum difference.

\section{Conclusion}

Sorghum is grass with high production potential in periods with water deficit due to its tolerance metabolism to certain adverse conditions. The use of Bacillus subtilis without algae extract promoted an increase in the stem diameter of sorghum plants. The absence of the bacteria promoted an increase in root volume, but regardless of the presence or absence of Bacillus subtilis, there was no statistical difference for dry mass accumulation. The application of algae extract did not influence the agronomic characteristics of sorghum plants.

\section{References}

[1] AQUINO, J. P. A.; MACEDO JUNIOR, F. B. de; ANTUNES, J. E. L.; FIGUEIREDO, M. do V. B.; ANCANTARA NETO, F. de; ARAUJO, A. S. F. de. Plant growth-promoting endophytic bacteria on maize and sorghum. Pesqui. Agropecu. Trop., Goiânia, v. 49, novembro, 2019. Disponível em: <http://www.scielo.br/scielo.php?script=sci_arttext\&pid $=$ S1983-40632019000100239\&lng=en\&nrm=iso $>$. Acesso em: 13 dez. 2019.

[2] ASSOCIAÇÃO BRASILEIRA DAS INDÚSTRIAS DE TECNOLOGIA EM NUTRIÇÃO VEGETAL (ABISOLO). Vantagens dos adubos complexados com algas. 2016. Disponível em: < https://abisolo.com.br/2016/03/24/vantagens-dosadubos-complexados-com-algas/>. Acesso em: 16 nov. 2019.

[3] BARBOSA, JC; MALDONADO, JUNIOR, W. 2015. AgroEstat - sistema para análises estatísticas de ensaios agronômicos. Jaboticabal: FCAV/UNESP. 396p.

[4] CAMARGO, P. N.; SILVA, O. Manual de adubação foliar. São Paulo: La Libreria, 1975. 258p.

[5] COELHO, A. M. Adubação foliar em milho utilizando fertilizantes multinutrientes. Campo e Negócios, Uberlândia, v. 92, n. 7, p.26-29, jan. 2018. Disponível em:

<https://www.alice.cnptia.embrapa.br/bitstream/doc/109 4860/1/Adubacaofoliar.pdf>. Acesso em: 13 dez. 2019.

[6] CUNHA, S. G. S. da; DAVID, A. M. S. de S.; AMARO, H. T. R.; PORTO, E. M. V. Qualidade fisiológica de sementes de sorgo em resposta ao tratamento com fertilizante à base de zinco e molibdênio. Revista Agrarian, Dourados, v.8, n.30, p.351-357, 2015. Disponível em: <http://ojs.ufgd.edu.br/index.php/agrarian/article/view/2 979/2705>. Acesso em: 13 dez. 2019.

[7] DANTAS, I. P. Riscos dos adubos químicos. 2010. Disponível em: < http://www.agricultura.al.gov.br/salade-imprensa/noticias/2010/setembro-3/riscos-dosadubos-quimicos>. Acesso em: 28 mar. 2019.

[8] EMBRAPA. Sistema brasileiro de classificação de solos. 3. ed. Brasília, DF: Embrapa Solos,2013. 352 p.

[9] FILHO, I. A. P.; RODRIGUES, J. A. S. O produtor pergunta, a Embrapa responde. Brasília, DF. 
Embrapa, 2015. Disponível em: < http://mais500p500r.sct.embrapa.br/view/pdfs/9000003 2-ebook-pdf.pdf>. Acesso em 28 mar. 2019.

[10]FREITAS, L. J. Avaliação dos efeitos de bioestimulantes na cultura do milho. 2019. $21 \mathrm{f}$. Trabalho de Conclusão de Curso (Graduação em Agronomia) - Universidade Federal de Uberlândia, Uberlândia, 2019.

[11]GALINDO, F. S.; TEIXEIRA FILHO, M. C. M.; BUZETTI, S.; ALVEZ, C. J.; GARCIA, C. M. de P.; NOGUEIRA, L. M. Extrato de algas como bioestimulante na nutrição e produtividade do trigo irrigado na região de Cerrado.

[12] Colloquium Agrariae, v. 15, n.1, Jan-Fev. 2019, p. 130140. Disponível em: <https://revistas.unoeste.br/index.php/ca/article/downlo ad/2346/2671>. Acesso em: 13 dez. 2019.

[13] GUEDES, Victor Hugo de Farias. Pulverização foliar de zinco com silício é viável agronomicamente para plantas de sorgo. 2019. 53 f. Dissertação (Mestrado) Curso de Engenharia Agronômica, Universidade Estadual Paulista, Jaboticabal, 2019. Disponível em: <https://repositorio.unesp.br/bitstream/handle/11449/18 3157/guedes_vhf_me_jabo.pdf?sequence $=5$ \&isAllowed =y>. Acesso em: 13 dez. 2019.

[14] HALPERN, M.; BAR-TAL, A.; OFEK, M.; MINZ, D.; MULLER, T.; YERMIYAHU, U. Chapter Two - The Use of Biostimulants for Enhancing Nutrient Uptake. In: SPARKS, D. L. (Ed.). Advances in Agronomy: Academic Press, v.130, 2015. p.141-174. ISBN 00652113.

[15]MARTINS, A. G.; SIEDEL, E. P.; RAMPIM, L.; ROSSET, J. S.; PRIOR, M.; COPPO, J. C. Aplicação de bioestimulante em sementes de milho cultivado em solos de diferentes texturas.Sci. Agrar. Parana, Marechal Cândido Rondon, v. 15, n. 4, out./dez., p. 440445, 2016. Disponível em: <http://erevista.unioeste.br/index.php/scientiaagraria/article/vie w/13028/10570>. Acesso em: 13 dez. 2019.

[16] NAKAO, A. H.; COSTA, N. R.; ADREOTTI, M.; SOUZA, M. F. P.; DICKMANN, L.; CENTENO, D. C.; CATALANI, G. C. Características agronômicas e qualidade fisiológica de sementes de soja em função da adubação foliar com boro e zinco. Cultura Agronômica, Ilha Solteira, v.27, n.3, p. 312-327, 2018. Disponível em:

https://ojs.unesp.br/index.php/rculturaagronomica/articl e/view/2577/2033>. Acesso em: 13 dez. 2019.

[17] OLIVEIRA, Kamilla Silva. Pulverização foliar de manganês com adição de silício é viável para plantas de milho e de sorgo. 2019. 49 f. Dissertação (Mestrado) - Curso de Engenharia Agronômica, Universidade Estadual Paulista, Jaboticabal, 2019. Disponível em: <https://repositorio.unesp.br/bitstream/handle/11449/18 1638/oliveira_ks_me_jabo.pdf?sequence=3\&isAllowed =y>. Acesso em: 13 dez. 2019.

[18] TORDIN, C. Cientistas usam bactérias para ajudar plantas a resistir à seca. Disponível em: <https://www.embrapa.br/busca-de-noticias//noticia/22885691/cientistas-usam-bacterias-paraajudar-plantas-a-resistir-a-seca>. Acesso em: 28 mar. 2019.

Volume 9 Issue 2, February 2020 